\title{
In silico study of 1,5-bis(4-hydroxy-3-methoxyphenyl)-1,4-pentadiene-3-one (Deketene Curcumin) on crystallized protein structures of SARS-CoV-2
}

\author{
Vraj Shah ${ }^{\mathrm{a}^{*}}$, Jaydip Bhaliya ${ }^{\mathrm{a}}$, Dhwani Shah ${ }^{\mathrm{b}}$
}

${ }^{a}$ Faculty of Life, Health \& Allied Sciences, ITM Vocational University, Vadodara-391760, Gujarat, India.

${ }^{b}$ Faculty of Pharmacy, The M.S. University of Baroda, Vadodara-390001, Gujarat, India.

\begin{abstract}
ABSTARCT
World Health Organization (WHO) reveals total number of coronavirus cases are 5,684,802 and 352,225 deaths till today worldwide. Coronavirus instances are nevertheless surging due to its speedy spreading through infected patients. Therefore, in order to find potent vaccine almost every researcher is doing hard work to find it. However, until today there is not any availability of effective vaccine or drug for the treatment of COVID-19. In this case, the computational approach is the good choice to identify effective drugs and could be very useful due to its low cost, less error and less time consumption. Here, Deketene curcumin has taken for docking study because of its lots of biological applications such as antiviral, antimicrobial, anti-inflammatory, antioxidant, antibiotic, and to a name of few, it is a derivative of curcumin. In this study, five main protease crystallized COVID-19 structures (PDB ID: 6LU7, 5R7Z, 5R7Y, 5R80, 5R81) have been taken for simulation against deketene curcumin. Required procedure for this in silico study done through Molegro virtual docker (MVD) and Molegro Molecular Viewer (MMV) used for visualization. The results showed H-bonding and steric interaction between Deketene Curcumin with COVID-19 (PDB ID: 6LU7, 5R7Z, 5R7Y, 5R80, 5R81). Moldock scores of Deketene Curcumin Observed $134.198 \mathrm{kcal} / \mathrm{mol},-151.972 \mathrm{kcal} / \mathrm{mol},-109.224 \mathrm{kcal} / \mathrm{mol},-140.741 \mathrm{kcal} / \mathrm{mol}$ and $-126.562 \mathrm{kcal} / \mathrm{mol}$ with PDB Id 6LU7, 5R7Z, 5R7Y, 5R80 and 5R81 respectively. As per our results, it can be say that Deketene Curcumin has effective as a lead compound to find new antiviral drug candidates against COVID-19 for possible medicinal agent.
\end{abstract}

Key words: - Coronavirus (COVID-19); Deketene Curcumin; Molecular Docking; Molegro Virtual Docker (MVD) 


\section{GRAPHICAL ABSTRACT}

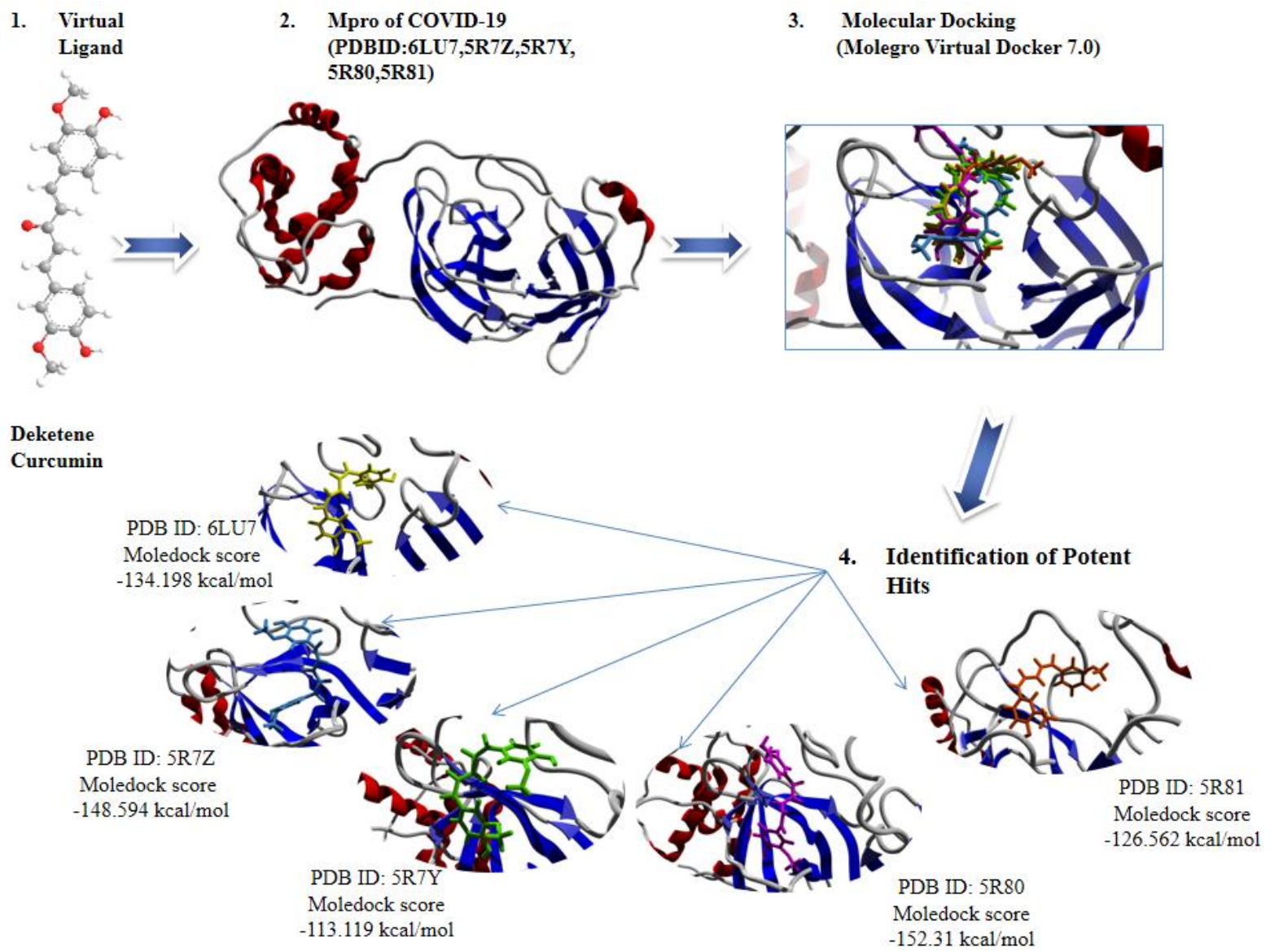

\section{INTRODUCTION}

SARS-CoV-2(severe acute respiratory syndrome coronavirus 2) which is originated from China. [1].The structure of the virus is might be pleomorphic or spherical, and it is characterised by using bears club-shaped projections of glycoproteins on its surface. This virus has a single-stranded RNA genome, covered through folded structure [2]. The symptoms of COVID-19 are more or less similar to SARS and MERS, the symptoms like fever, fatigue, dry cough, myalgia, and dyspnea. Sputum production, headache, haemoptysis, and diarrhea would be the unusual sign of the infected patients [3]. The current data shows major transmission routes are sneezing droplets and air [4]. For the diagnosis usually doctors look person travel history, symptoms related with COVID-19 and so on, the nasopharyngeal swab from the nose is the most common specimens for the detection of coronavirus. [5, 6]. Nowadays every scientist and researcher is finding a way to cure this pandemic COVID-19 through developing different types of medicines. Despite this, scientists are failed to develop effective or potent drugs for the prevention of the same [7].To overcome this global challenge, Pharmacophore and computational approach can be the backbone for many researchers [8].

In this research, Deketene curcumin is used for molecular docking with the five crystallized protein structures of COVID19(PDB ID: 6LU7, 5R7Z, 5R7Y, 5R80, 5R81). In Ayurveda, curcumin is widely used for several treatment aspects because of the therapeutic properties like anti-oxidant, antiviral, antiseptic, analgesic, antimalarial, and anti-inflammatory [9]. Although curcumin (1,7-bis (4-hydroxy-3-methoxyphenyl)-1,6-heptadiene-3,5-dione) provides lots of medicinal applications but, there are some drawbacks of curcumin such as the less bioavailability of orally administered curcumin, it shows minimal buffer and plasma stability, and other factors. Therefore, Modification in curcumin is required one of the potent compound is deketene curcumin (1, 5-bis (4-hydroxy-3-methoxyphenyl)-1, 4-pentadiene-3-one) [10]. Henceforth, This particular derivative of curcumin (deketene curcumin) has been chosen for simulation against COVID-19. 
This paper reports screening of deketene curcumin bound directly or indirectly to five Crystallized protein structure of COVID-19 extracted from the protein data bank, by utilizing the Molegro Virtual Docker Software. Moreover, deketene curcumin inhibitors that target COVID-19 are considered as effective therapeutic agents to fight against COVID-19.

\section{Material and Method}

\subsection{Protein and Ligand preparation}

The three-dimensional crystal structures of Covid-19 main protease (PDB ID: 6LU7, 5R7Z, 5R7Y, 5R80, 5R81) determined by X-ray crystallography had been retrieved from Protein Data Bank (http://www.rcsb.org) and it was imported in the Molegro Virtual Docker (MVD 7.0 Molegro Virtual Docker, DK- 8000 Aarhus C, Denmark). All the crystals structures have only one chain called (A). When these PDB id downloaded they combined with the water molecules and co-factors which manually removed in the software. Furthermore, the ligand directly obtained from pubchem database, the 2D and 3D structures of ligand-Deketene curcumin illustrated in Fig.1. The enery minimization of compound done by using Chem bio draw 3D software then it saved in SDF format which further use in docking process with protein.

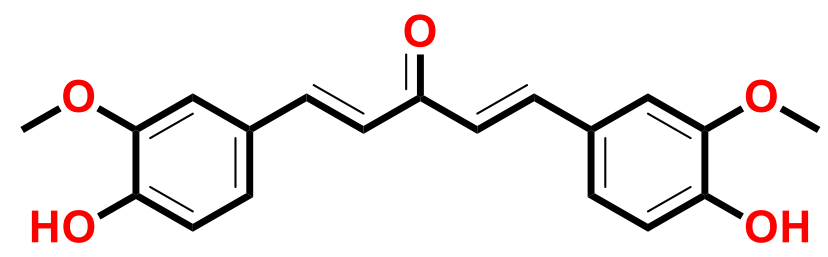

(A)

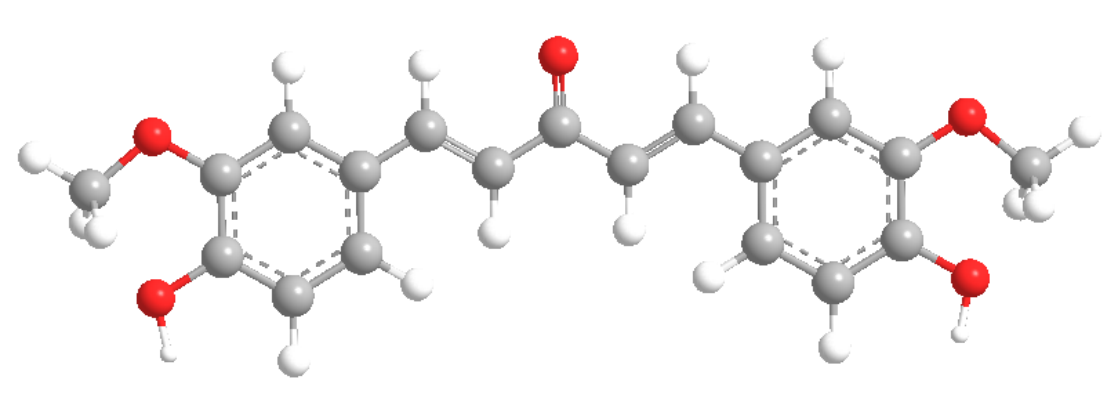

(B)

Figure 1: 2D representation of deketene curcumin (A), 3D representation of deketene curcumin (B)

\subsection{Cavity detection and selection}

Possible active site/cavities for the target main protease of COVID-19(PDB ID: 6LU7, 5R7Z, 5R7Y, 5R80, 5R81) of interest had been determined with the help of Molegro Virtual Docker (MVD) [13]. Only one cavity had been selected as an active site on the basis of prior information about the active site residues. Detected cavities for all crystal structures of COVID-19 (PDB ID: 6LU7, 5R7Z, 5R7Y, 5R80, 5R81) are illustrate in Figure 2. From these predicated cavities the one with highest volume $131.584 \AA^{3}, 115.2 \AA^{3}, 113.664 \AA^{3}, 160.256 \AA^{3}$ and 52.736 $\AA^{3}$ for the Mpro of Covid-19 6LU7, 5R7Z, 5R7Y, 5R80, and $5 \mathrm{R} 81$ respectively. The selected cavity used for ligand-protein binding study. 


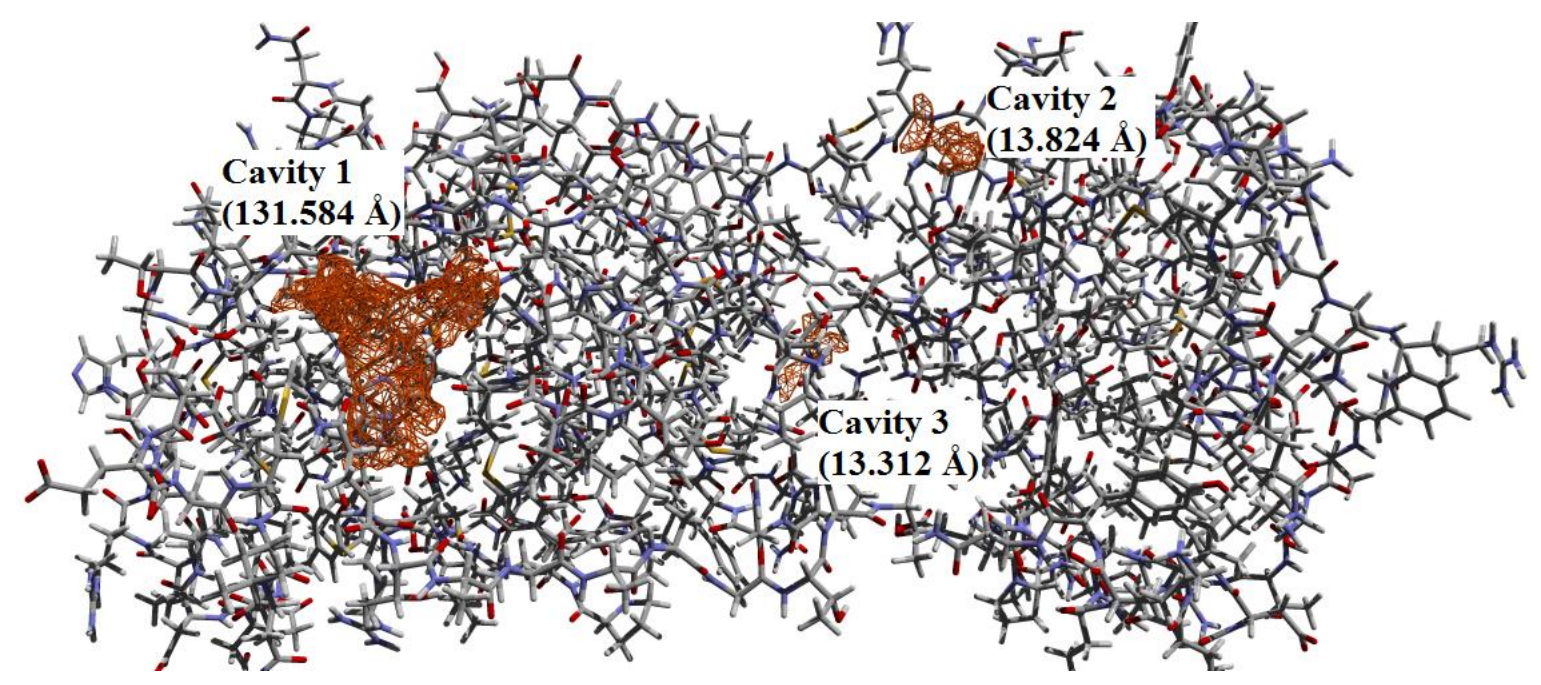

(A) : Detected Cavity in COVID-19 (PDB ID :6LU7)

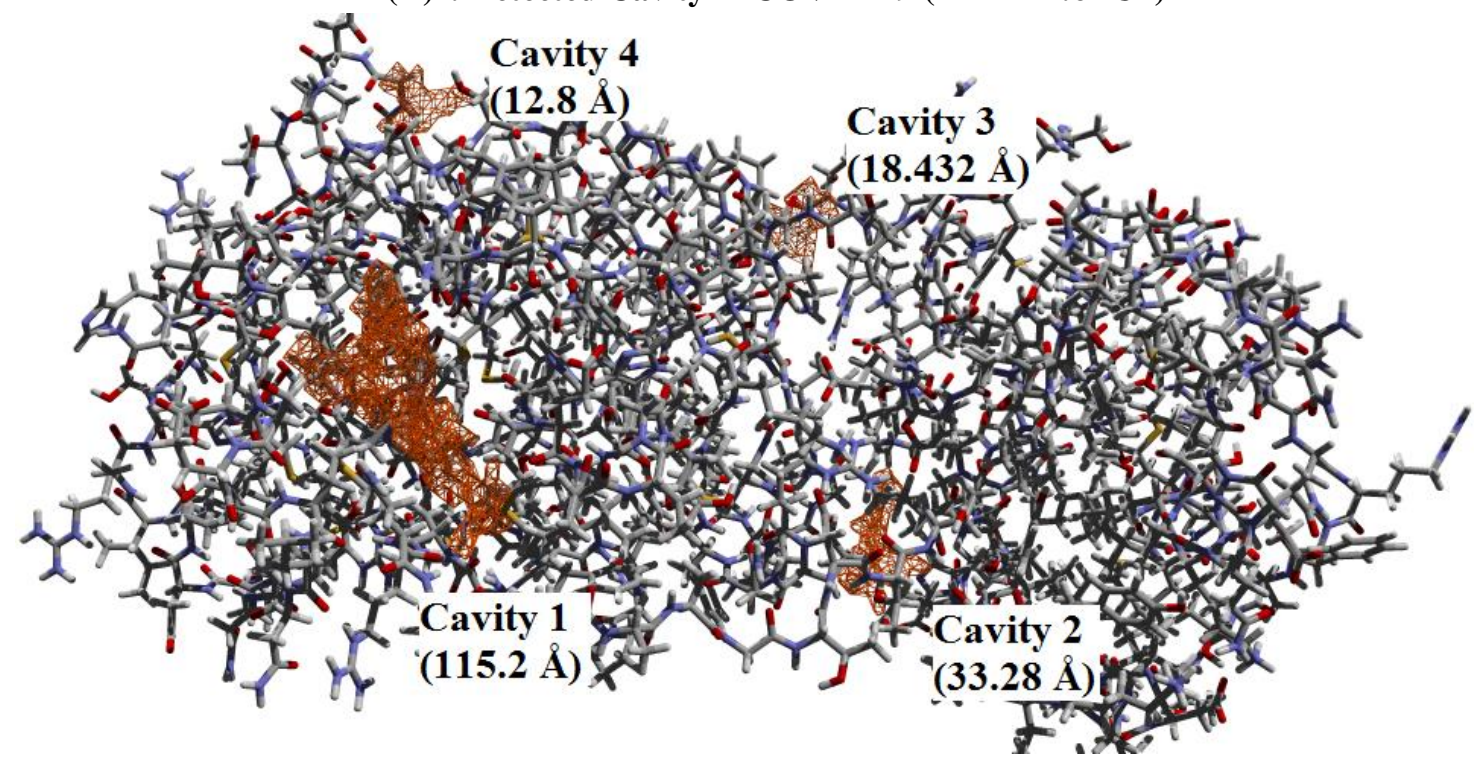

(B) : Detected Cavity in COVID-19 (PDB ID : 5R7Z)

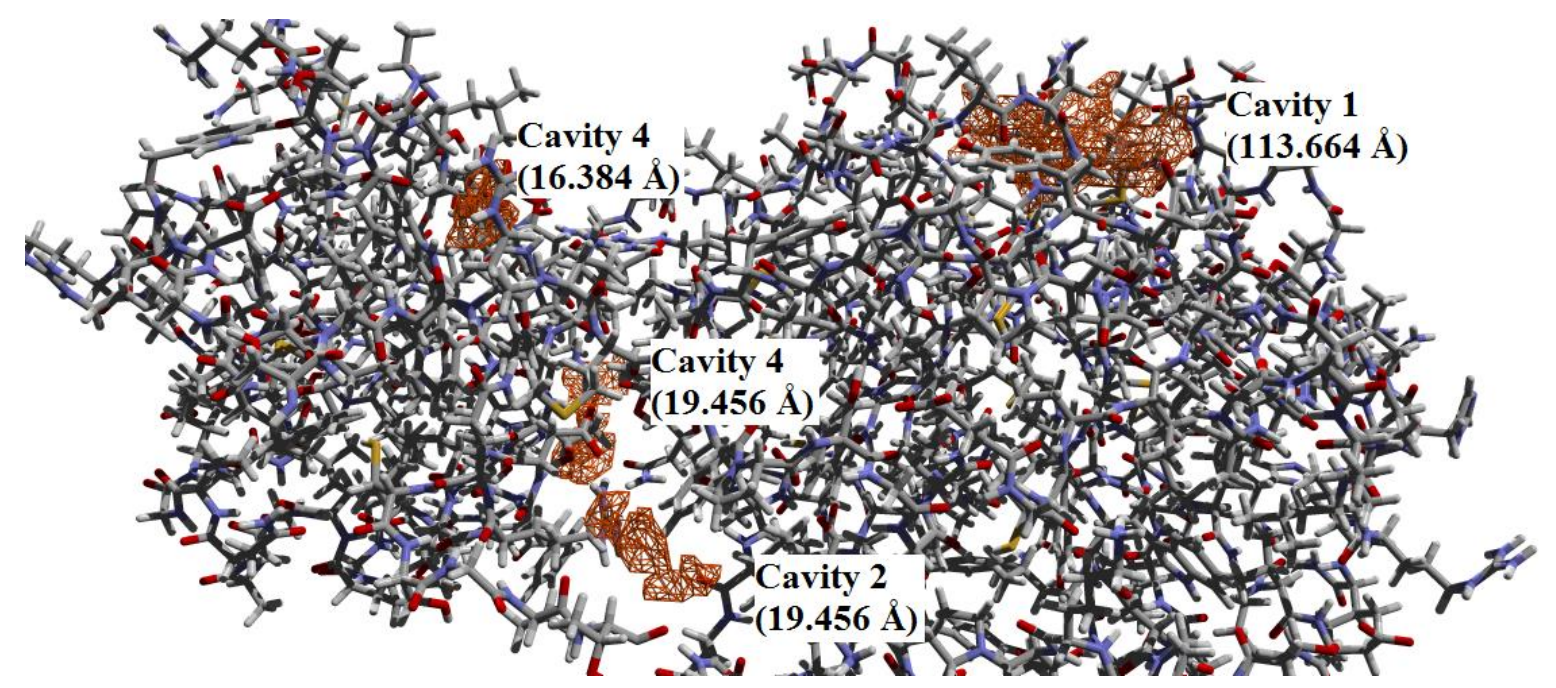

(C) : Detected Cavity in COVID-19 (PDB ID : 5R7Y) 


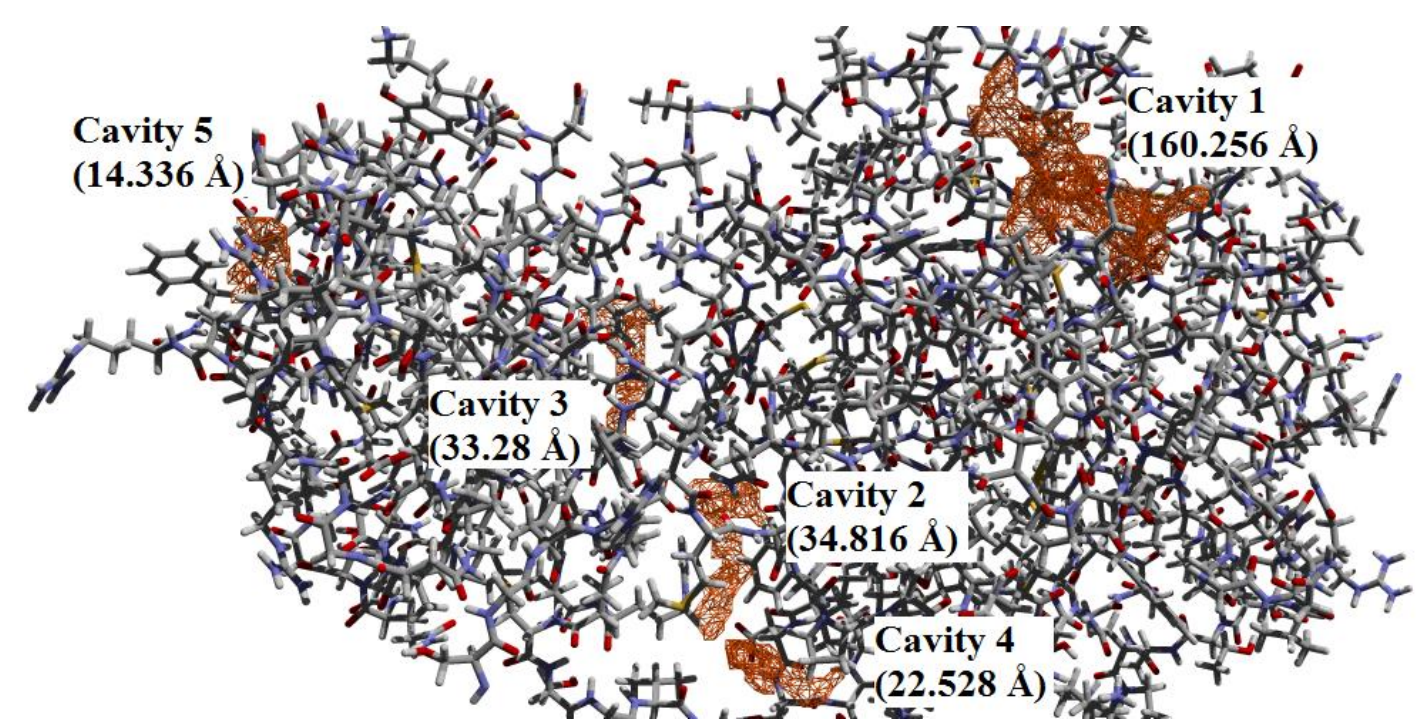

(D) : Detected Cavity in COVID-19 (PDB ID : 5R80)

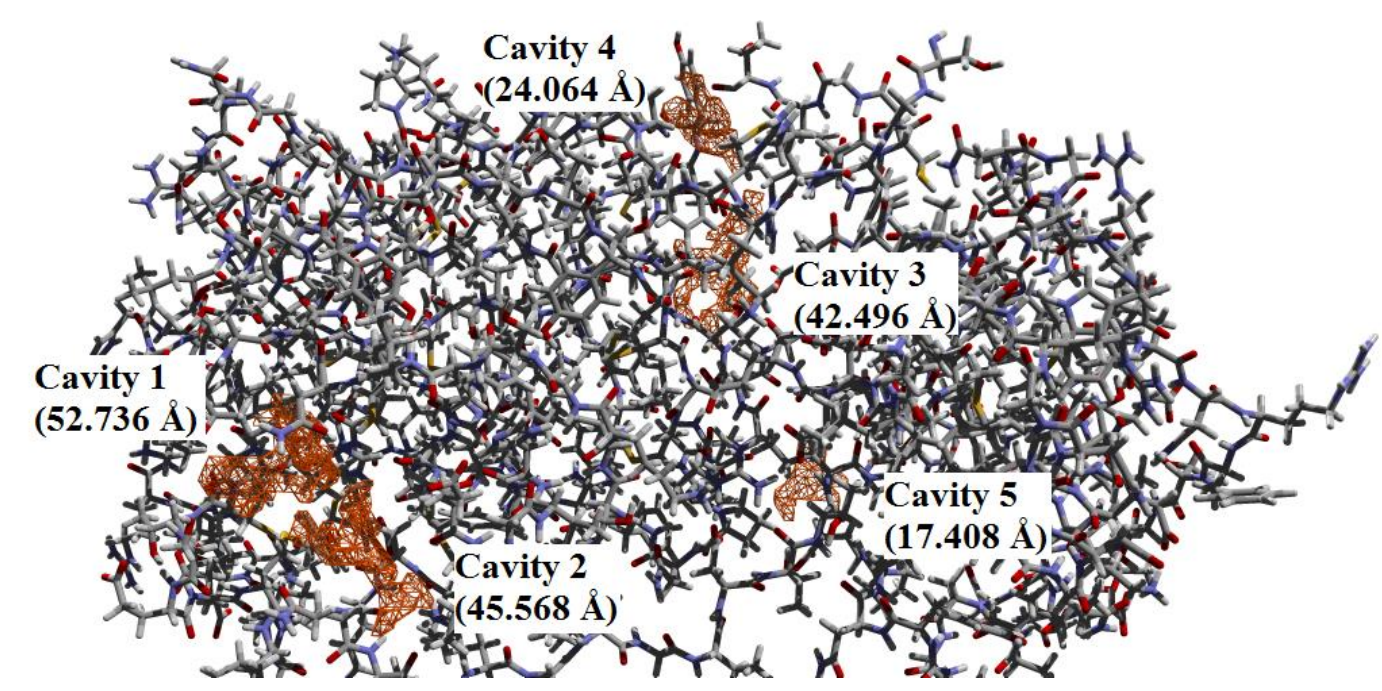

(E) : Detected Cavity in COVID-19 (PDB ID : 5R81)

Figure 2: MVD-detected cavities in COVID-19 Mpro, and their calculated volumes (in Å) (PDB ID :6LU7 (A), 5R7Z (B), 5R7Y (C) , 5R80 (D), 5R81(E) ), detected cavity orange, oxygen atoms red,carbon atoms grey, nitrogen atoms blue, hydrogen atoms white

\subsection{Molecular docking studies}

The Molegro Virtual Docker (MVD) software has been used to perform molecular docking procedure [13].In this study, docking of deketene curcumin against COVID-19 has performed using MVD software. Protein of COVID-19 held in the Protein Data Bank (PDB) get through the URL (http://www.rscb.org/pdb) under the criteria that they had reasonable resolution $2.16 \AA$ 足 $1.59 \AA$ A $1.65 \AA, 1.93 \AA$ and $1.95 \AA$ of PDB ID 6LU7, 5R7Z, 5R7Y, 5R80, and 5R81 respectively.After importing a main protease of COVID-19 in the MVD program, deketene curcumin have been docked against COVID-19 crystal structure. The GRID resolution had been set to $0.35 \AA$, the centre of binding sites had been set on the Coordinates values $X=-10.6521$, $Y=15.3393, Z=68.1447$ for $6 L U 7, X=8.9511, Y=-1.17547, Z=23.9226$ for $5 R 7 Z, X=9.58477, Y=-0.569185, Z=24.2391$ for 5R7Y, $X=9.22974, Y=-0.794554, Z=22.7438$ for $5 R 80$ and $X=8.00856, Y=-4.04292, Z=24.7347$ for $5 R 81$. Set a parameters were used including maximum iteration of 2000 and a maximum population size of 100 . The software consist an algorithm which use to run ten independent runs and each of the run back to give pose. Moreover, in order to get excellent visualization molegro molecular viewer (MMV) was used. 


\section{RESULT AND DISCUSSION}

To find out a potential candidate as medicine or drug, molecular studies were done through deketene curcumin on the binding pocket of protein COVID-19(PDB ID: 6LU7, 5R7Z, 5R7Y, 5R80, 5R81) due to its plethora medicinal applications such as anti-oxidant, antiviral, antiseptic, analgesic, antimalarial, and anti-inflammatory. It is a fact that, Molegro Virtual Docker is one of the accurate software for simulation as it is acknowledged by many researchers. Moreover, this software has proven to be successful, very affordable as well as less time consuming [11].

The molecular docking approach was used to determine a potent inhibitor, which will show the best binding energy with the selected COVID-19 Mpro. Deketene curcumin was docked against each of 5 Mpro of Covid-19 (namely PDB ID: 6LU7, 5R7Z, 5R7Y, 5R80, 5R81) using Molegro Virtual Docker (MVD) tool. With this study; it was found that Deketene Curcumin docking score with all 5 Mpro of Covid-19 was showing the highest binding affinity, as binding energy obtained in negative values indicates that the scores obtained are highly efficient. The following table 1 shows the top docking poses ranked according to their binding energy.The Moldock score and the re-rank scores of the best poses for each of the docking studies of deketene curcumin with COVID-19 are presented in Table 1. In table 1show, H-bond means the hydrogen bonding which occurs between protein and ligand. Another important factor is steric which means the interaction of energy between protein and ligand [12]. LE1 and LE3 are the ligand efficiency 1 and ligand efficiency 3 respectively [13].

Table 1: MolDock and Re-rank score (kcal/mol) for Deketene Curcumin docked against Covid-19 crystal structures (PDB ID: 6LU7, 5R7Z, 5R7Y, 5R80, 5R81)

\begin{tabular}{|c|c|c|c|c|c|c|c|c|c|c|}
\hline Ligand & $\begin{array}{c}\text { PDB } \\
\text { ID }\end{array}$ & $\begin{array}{c}\text { E-Inter } \\
\text { (protein- } \\
\text { ligand } \\
\text { interaction } \\
\text { energy in } \\
\text { kcal/mol) }\end{array}$ & $\begin{array}{c}\begin{array}{c}\text { Energy } \\
(\mathrm{kcal} / \mathrm{mol}) \\
\text { or }\end{array} \\
\text { MolDock Score }\end{array}$ & $\begin{array}{c}\text { H-bond } \\
\text { Energy } \\
(\text { kcal/mol) }\end{array}$ & $\begin{array}{c}\text { Rerank } \\
\text { score } \\
(\mathbf{k c a l} / \mathbf{m o l})\end{array}$ & $\begin{array}{c}\text { Steric } \\
\text { interaction } \\
(\mathrm{kcal} / \mathrm{mol})\end{array}$ & LE1 & LE3 & $\begin{array}{c}\text { VdW } \\
(\text { LJ12-6) } \\
\text { (kcal/mol) }\end{array}$ & $\begin{array}{c}\text { No of } \\
\text { H-bonds }\end{array}$ \\
\hline \multirow{5}{*}{$\begin{array}{l}\text { Deketene } \\
\text { curcumin }\end{array}$} & 6LU7 & -151.58 & -134.198 & -6.62577 & -96.9185 & -144.954 & -5.59157 & -4.03827 & -32.9508 & 7 \\
\hline & $5 \mathrm{R} 7 \mathrm{Z}$ & -148.594 & -151.972 & -4.12536 & -111.436 & -144.469 & -6.33218 & -4.64315 & -42.1601 & 6 \\
\hline & $5 \mathrm{R} 7 \mathrm{Y}$ & -113.119 & -109.224 & -7.37741 & -79.3735 & -105.742 & -4.551 & -3.30723 & -34.3406 & 6 \\
\hline & $5 \mathrm{R} 80$ & -152.31 & -140.741 & -6.21687 & -98.2749 & -146.093 & -5.86423 & -4.09479 & -46.0229 & 5 \\
\hline & 5R81 & -115.931 & -126.562 & -4.19462 & -90.5326 & -111.736 & -5.27341 & -3.77219 & -34.2131 & 4 \\
\hline
\end{tabular}

Molecular docking study through MVD revealed Moldock score between -113.119 to $-151.58 \mathrm{kcal} / \mathrm{mol}$, in which deketene curcumin shows the lowest energy with PDB ID: 5R80 Mpro of COVID -19. Moreover Deketene Curcumin can bind with all Mpro of COVID-19. The Binding of deketene curcumin with all Mpro of Covid-19 are presented in Figure 3 to 7. In which The best score docking solution of deketene curcumin with the five selected crystal structure of COVID-19, Amino acids in the active site are presented in Ball-stick with element colour (where oxygen is red, carbon is grey, nitrogen is blue, hydrogen is white and sulphur is yellow ) and Deketene Curcumin is presented in Stick lines with fix colour yellow for 6LU7, Blue for $5 R 7 Z$, green for 5R7Y, pink for 5R80 and orange for 5R81. Blue lines represent the hydrogen bonds between the Deketene curcumin and the active site of COVID-19 Mpro. 


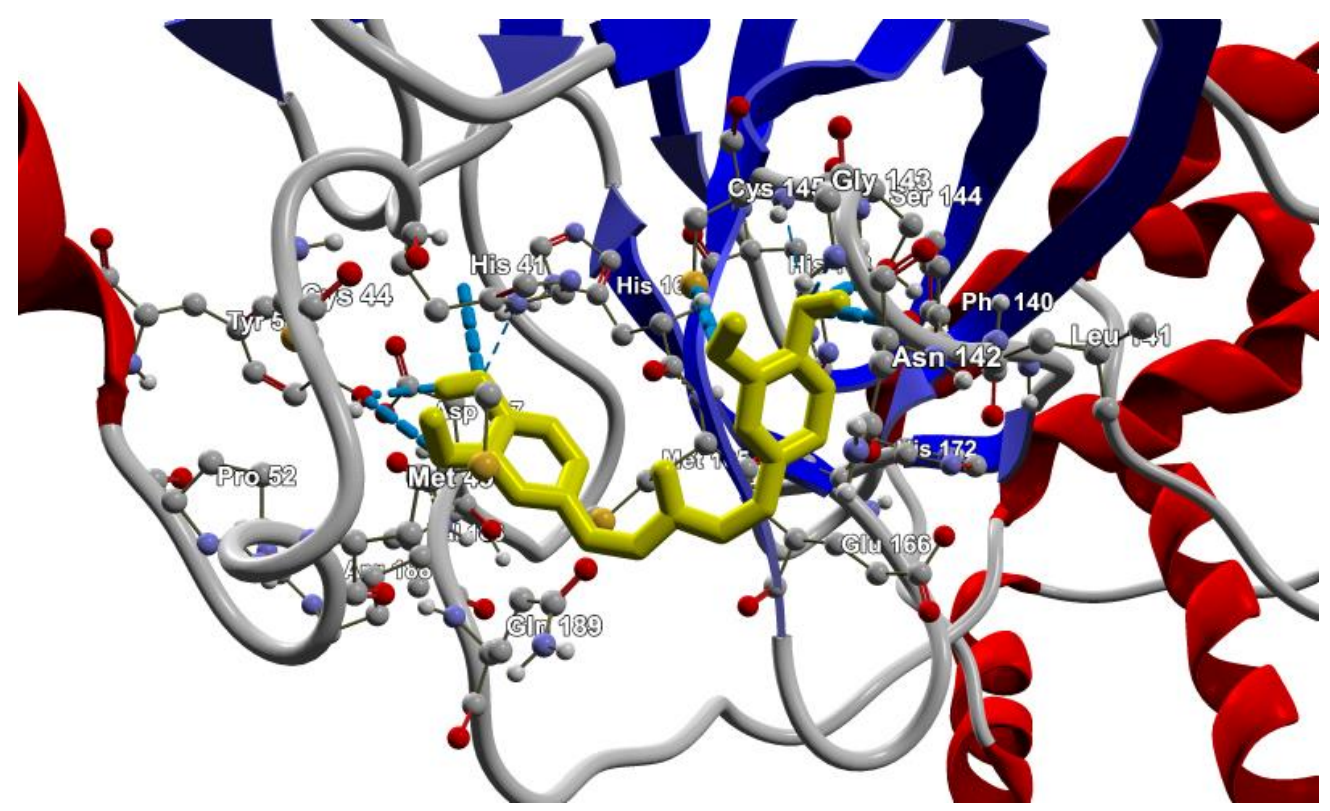

Figure 3:6LU7 docked with Deketene Curcumin showing various interactions with amino acids - Cyr 145, Leu 141, Ser 144, Tyr 54 and His 41

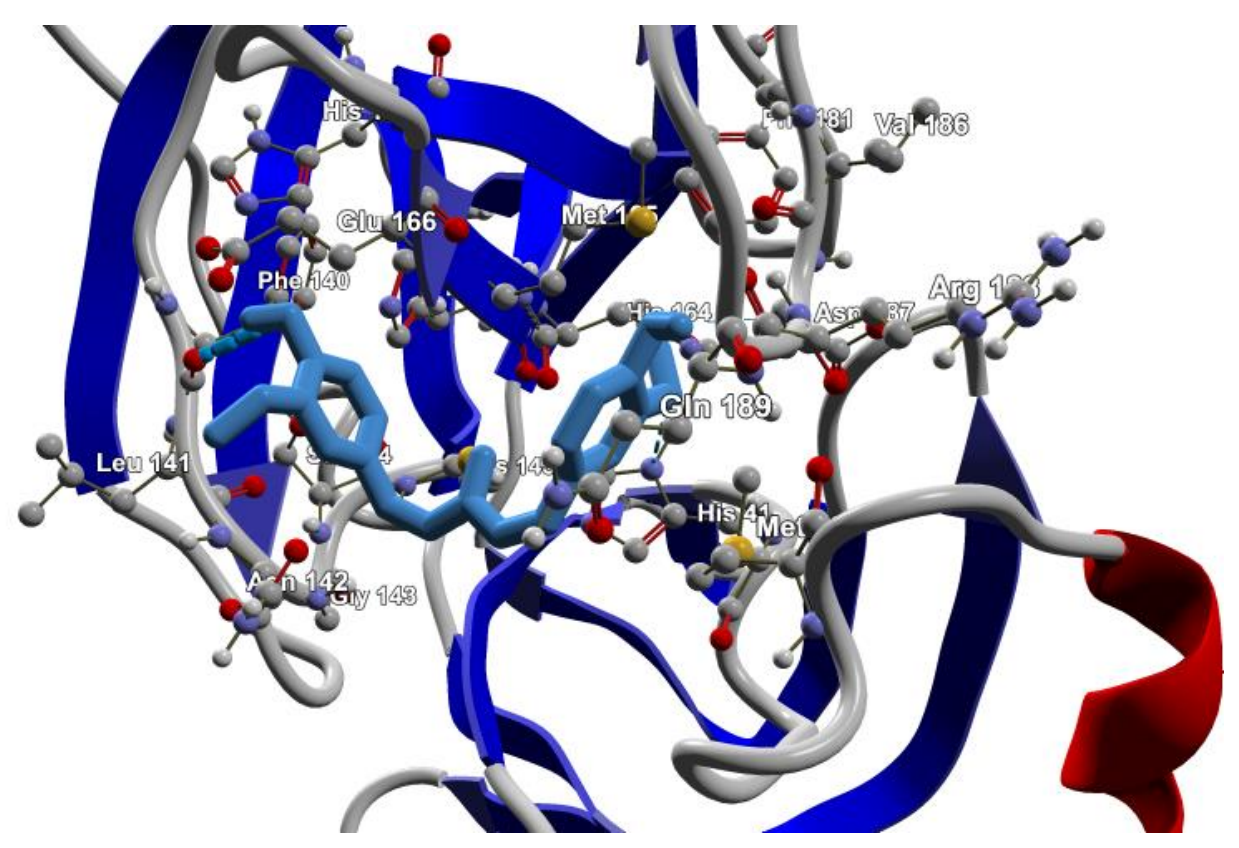

Figure 4: 5R7Z docked with Deketene Curcumin showing various interactions with amino acids - Glu 166, Phe 140, His 172, Cyr 145, Arg 188 and His 41 


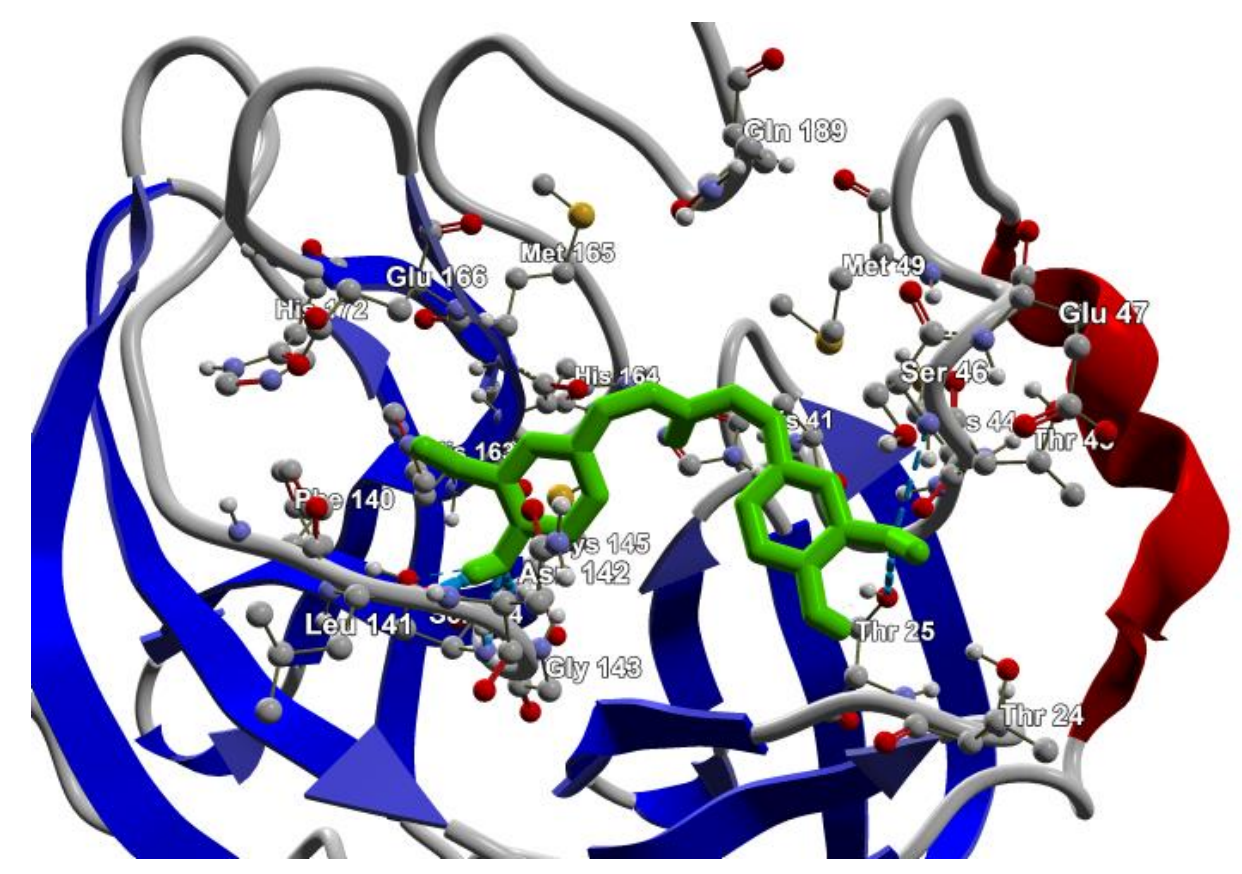

Figure 5: 5R7Y docked with Deketene Curcumin showing various interactions with amino acids - Thr 25, Ser 46, Cyr 145, Ser 144 and Leu 141

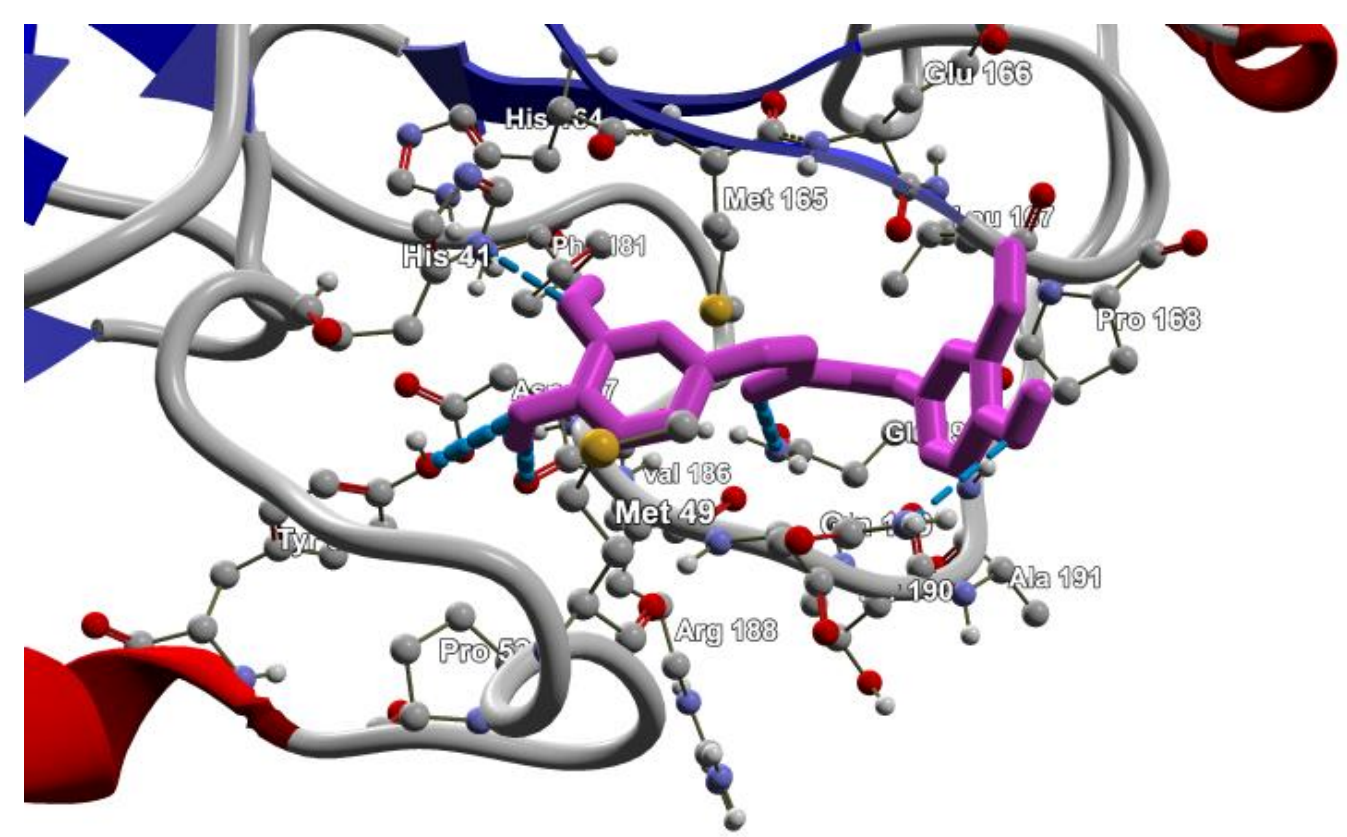

Figure 6:5R80 docked with Deketene Curcumin showing various interactions with amino acids - Asp 187, Tyr 54, His 41, Gln 192 and Gln 189 


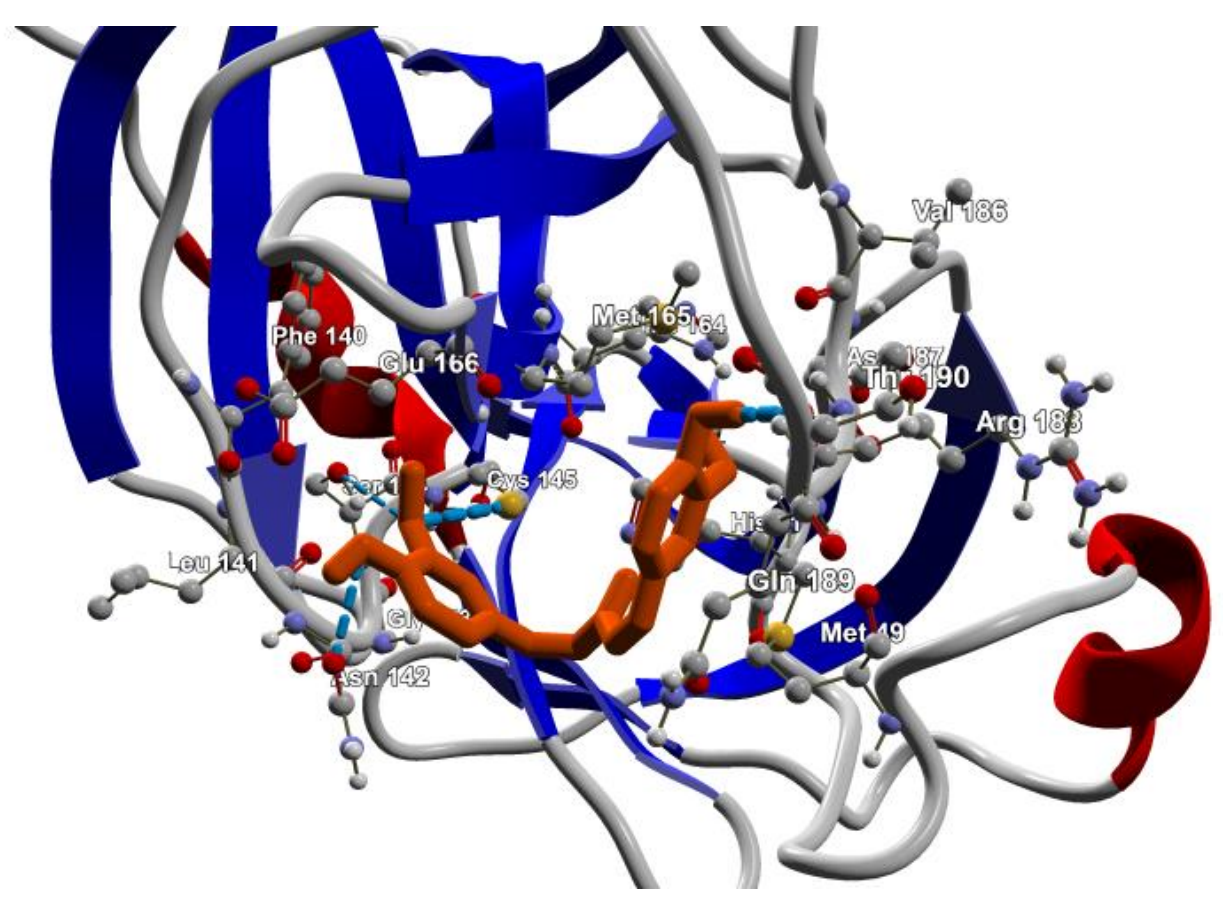

Figure 7: 5R81 docked with Deketene Curcumin showing various interactions with amino acids - Asn 142, Cyr 145, Ser 144 and Arg 188

Deketene curcumin known as 1, 5-bis (4-hydroxy-3-methoxyphenyl)-1, 4-pentadiene-3-one docked against five main protease of Covid-19,in which mostly observed that present oxygen atom in hydroxyl, methoxy and carbonyl of Deketene Curcumin are formed hydrogen bond between all COVID-19 main protease with a ligand. Also these three groups take part in forming a steric interaction.

Docking of Covid-19 PDB Id: 6LU7 with a ligand, the results showed seven hydrogen bonding between the Mpro and ligand atoms. The interaction residues include Cyr 145, Leu 141, Ser 144, Tyr 54, and His 41 (Figure 8a). Hydroxyl group of deketene curcumin interacts by forming H-bond with amino acid Cys 145, Leu 141, Ser 144, and His 41. Furthermore, H-bond interaction is observed between amino acid Tyr 54 and the methoxy group of a ligand. Besides, the ligand was observed with steric interactions and residue Glu 166, His 163, Met 165, Gln 189, His 41, and Asp 187 involved in the interaction (Figure 9a).

In the case of Covid-19 PDB Id: 5R7Z with a ligand, the results showed six hydrogen bonding between the Mpro and ligand atoms. The interaction residues include Glu 166, Phe 140, His 172, Cys 145, Arg 188, and His 41 (Figure 8b). Hydroxyl group of deketene curcumin interacts by forming H-bond with amino acid Glu 166, Phe 140, His 172, and Arg 188. Carbonyl group interacts with Cys 145 amino acid and the methoxy group interacts with His 41. Besides, the deketene curcumin ligand was observed with 8 steric interactions that were observed and residues His 163, Phe 140, His 142, Asn 142, Cys 145, Met 165, Asp 187 and His 164 involved in the interaction (Figure 9b ).

In the case of Covid-19 PDB Id: 5R7Y with deketene curcumin, the results showed six hydrogen bonding between the Mpro and ligand atoms. The interaction residues include Thr 25, Ser 46, Cys 145, Ser 144, and Leu 141 (Figure 8c). Hydroxyl group of deketene curcumin interacts by forming H-bond with amino acid Thr 25, Cys 145, Ser 144, and Leu 141. Methoxy group of deketene curcumin interacts with Ser 46 amino acid of Covid-19 Mpro (PDB Id: 5R7Y). In addition, the deketene curcumin ligand was observed with 5 steric interactions that were observed and residues Met 49, Ser 46, His 41, Cys 145, and His 163 involved in the interaction (Figure $9 b$ ).

In the case of Covid-19 PDB Id: 5R80 with deketene curcumin, the results showed five hydrogen bonding between the Mpro and ligand atoms. The interaction residues include Asp 187, Tyr 54, His 41, Gln 192, and Gln 189 (Figure 8d). Hydroxyl group of deketene curcumin interacts by forming H-bond with amino acid Asp 187, Tyr 54, and Gln 189. Methoxy group of deketene curcumin interact with His 41 and Carbonyl group interact with Gln 192 amino acid of Covid-19 Mpro (PDB Id: 5R80). In addition, the deketene curcumin ligand was observed with 5 steric interactions that were observed and residues Met 49, Ser 46, His 41, Cys 145, and His 163 involved in the interaction (Figure 9d).

In the case of Covid-19 PDB Id: 5R81 with deketene curcumin, the results showed four hydrogen bonding between the Mpro and ligand atoms. The interaction residues include Asp 142, Cys 145, Ser 144, and Arg 188 (Figure 8e). Hydroxyl group of deketene curcumin interacts by forming H-bond with amino acid Asn 142 and Arg 188. Methoxy group of deketene curcumin 
interacts with Cys 145 and Ser 144 of Covid-19 Mpro (PDB Id: 5R81). In addition, the deketene curcumin ligand was observed with 4 steric interactions had been seen and residues Asp 142, Leu 141, Cys 145, and Met 49 involved in the interaction (Figure 9e). Overall it can be stated that deketene curcumin has a good binding affinity with COVID-19 main protease. Deketene curcumin fits well in the active sites of COVID-19(namely PDB ID: 6LU7, 5R7Z, 5R7Y, 5R80, 5R81). Figure 8 shows hydrogen bonding with COVID-19 and Figure 9 shows steric interaction with COVID-19. Fig 10 showed the binding of deketene curcumin in the active site of Covid-19 main protease (Mpro) (PDB ID: 6LU7, 5R7Z, 5R7Y, 5R80, 5R81). It showed clear binding of DeketeneCurcumin. In addition to this, based on this docking study deketene curcumin reflects as a potent drug against COVID-19.

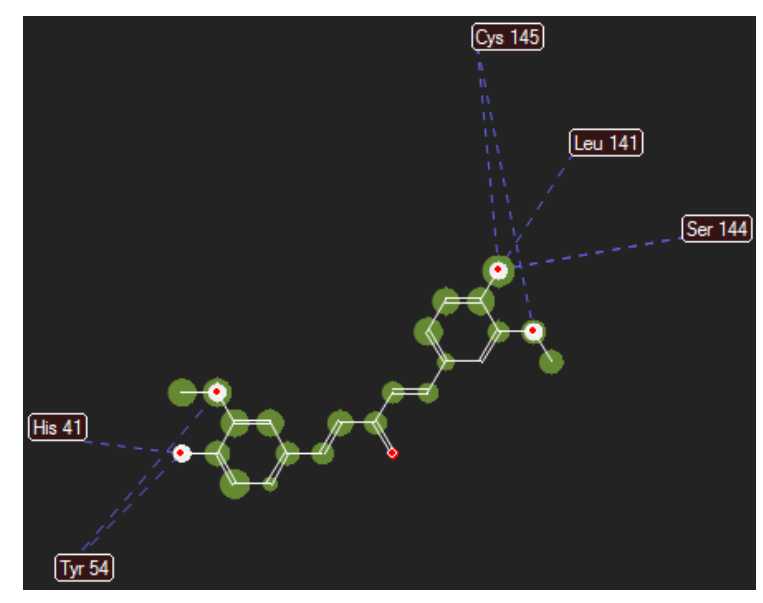

6LU7 (8a)

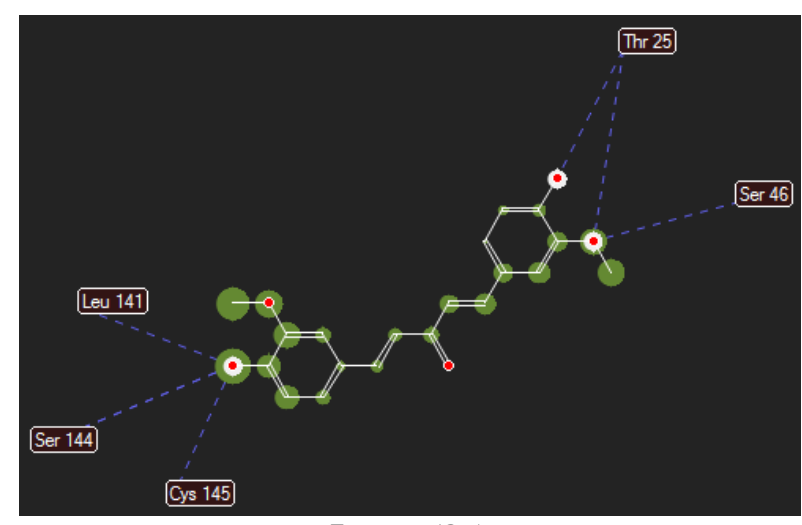

5R7Y (8c)

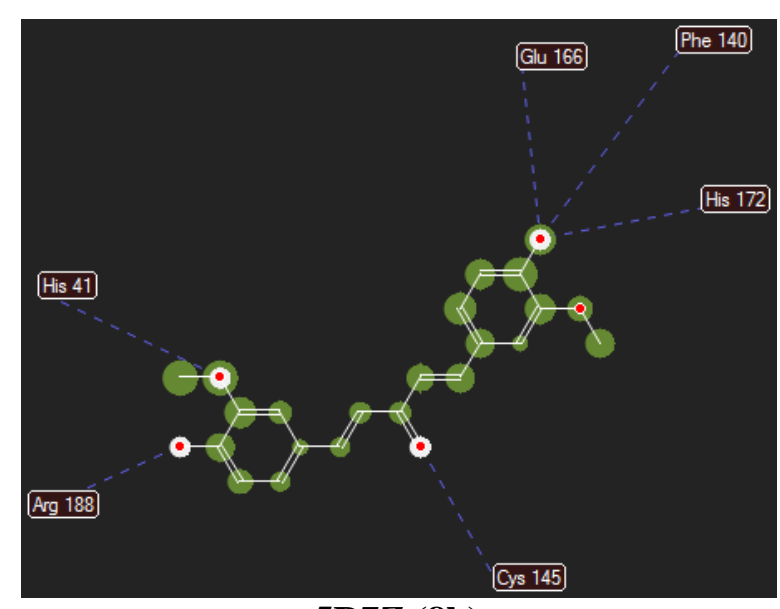

5R7Z (8b)

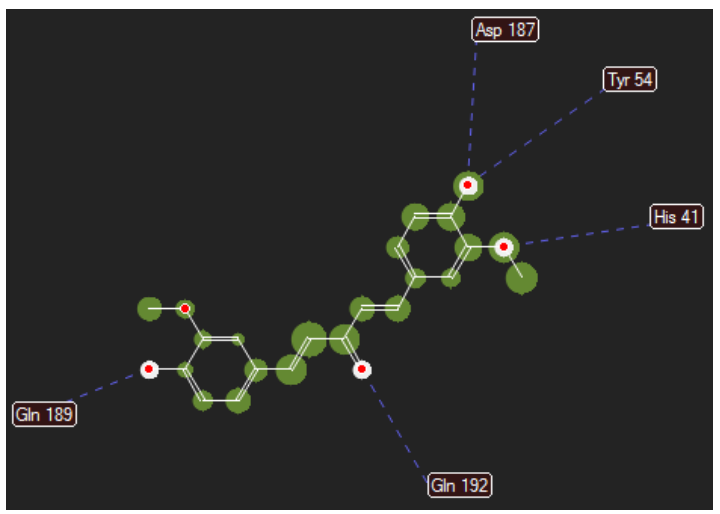

$5 R 80(8 d)$

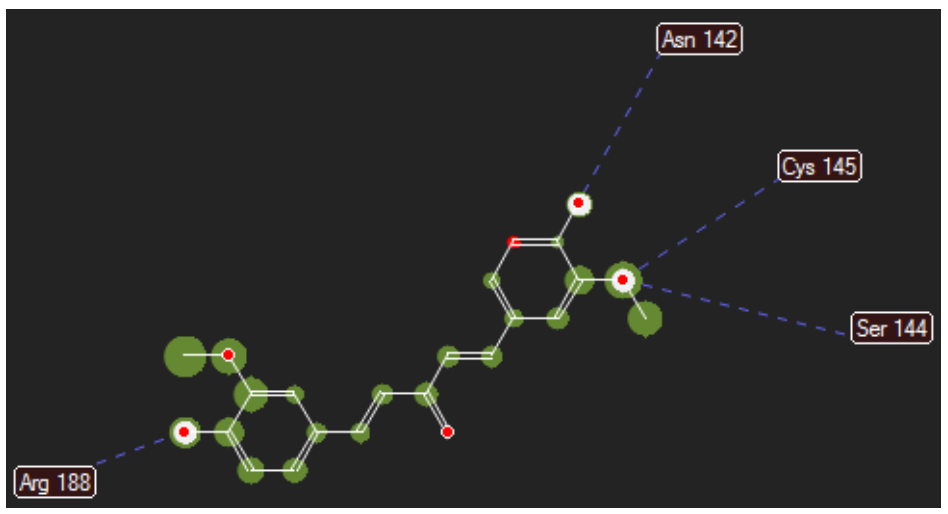

5R81 (8e)

Figure 8(a-e): Hydrogen bond interaction between DeketeneCurcuminwith five Covid-19 Mpro 6LU7 (8a), 5R7Z (8b), 5R7Y (8c), 5R80 (8d) and 5R81 (8e). 


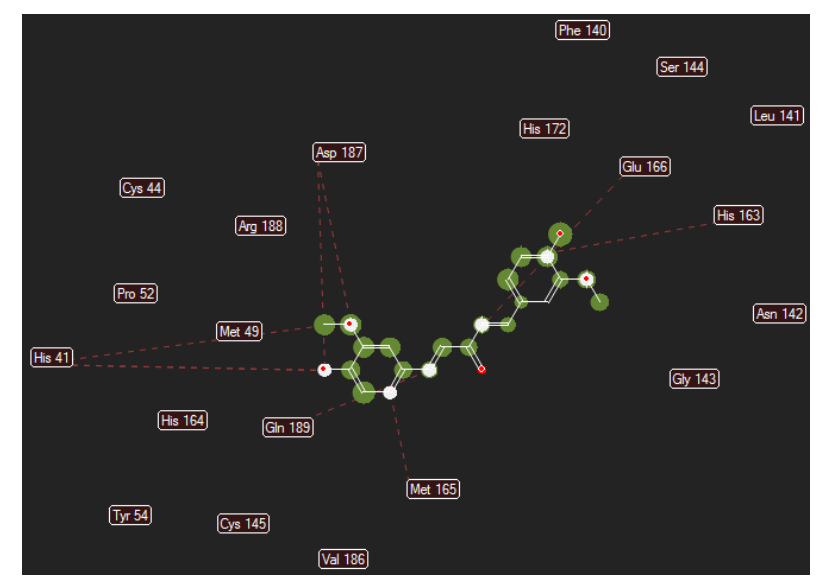

6LU7 (9a)

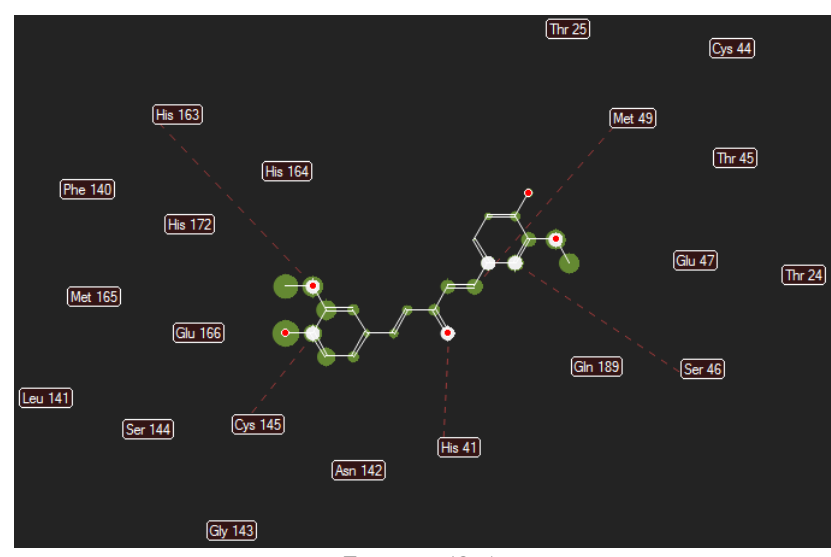

5R7Y (9c)

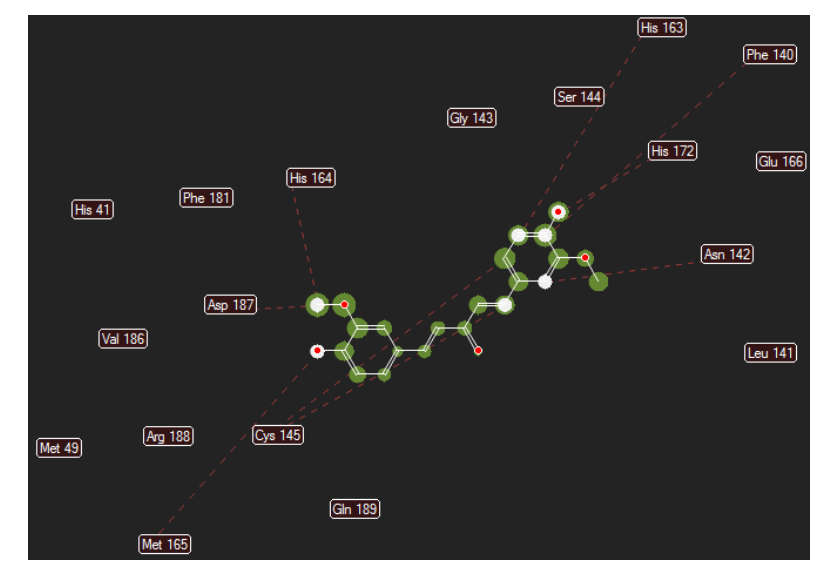

5R7Z (9b)

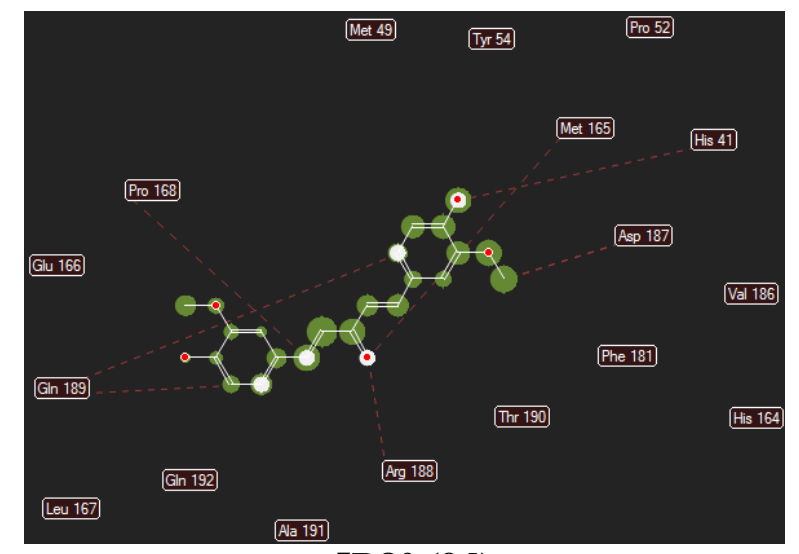

$5 R 80(9 d)$

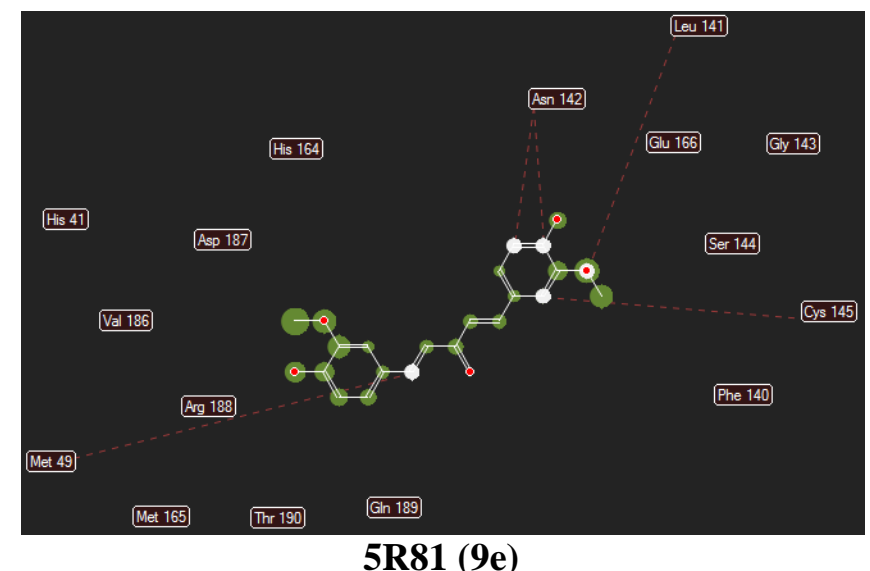

Figure 9(a-e): Steric interaction between Deketene Curcumin with five Covid-19 Mpro 6LU7 (9a), 5R7Z (9b), 5R7Y (9c), 5R80 (9d) and 5R81 (9e). 


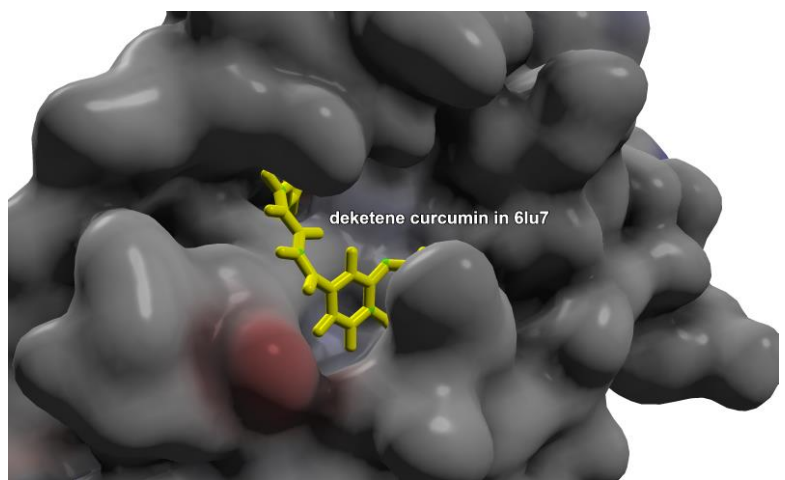

6LU7 (10a)

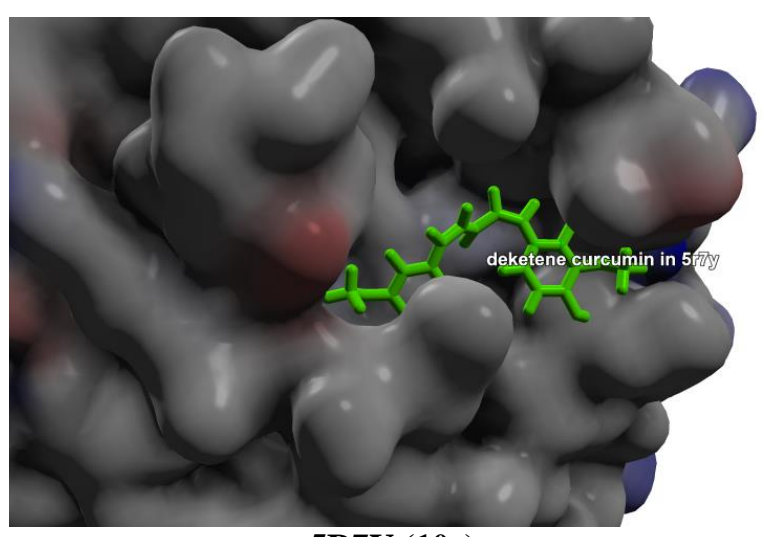

5R7Y (10c)

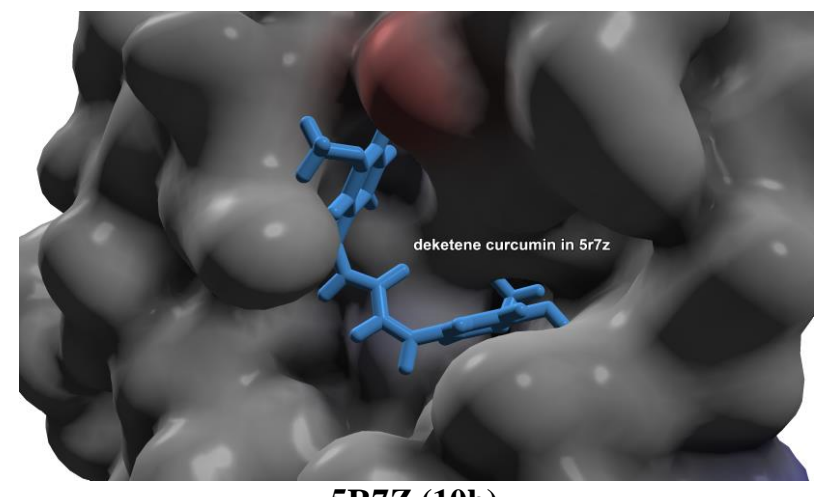

5R7Z (10b)

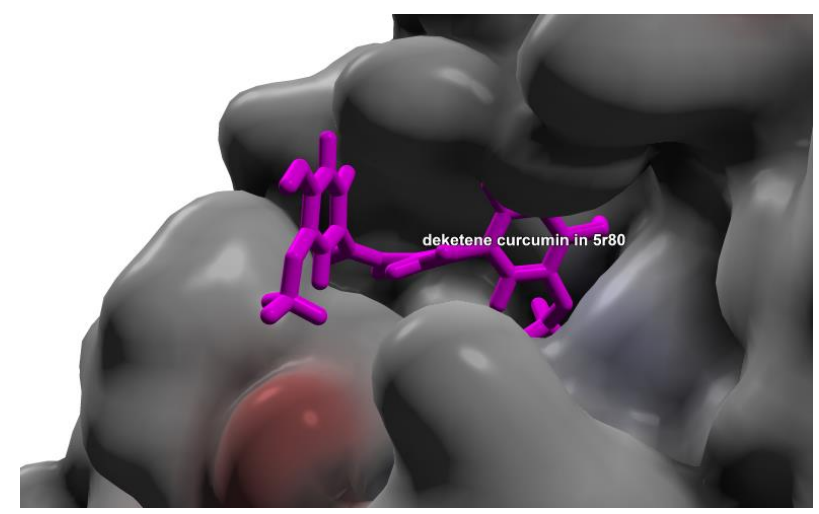

$5 R 80(10 d)$

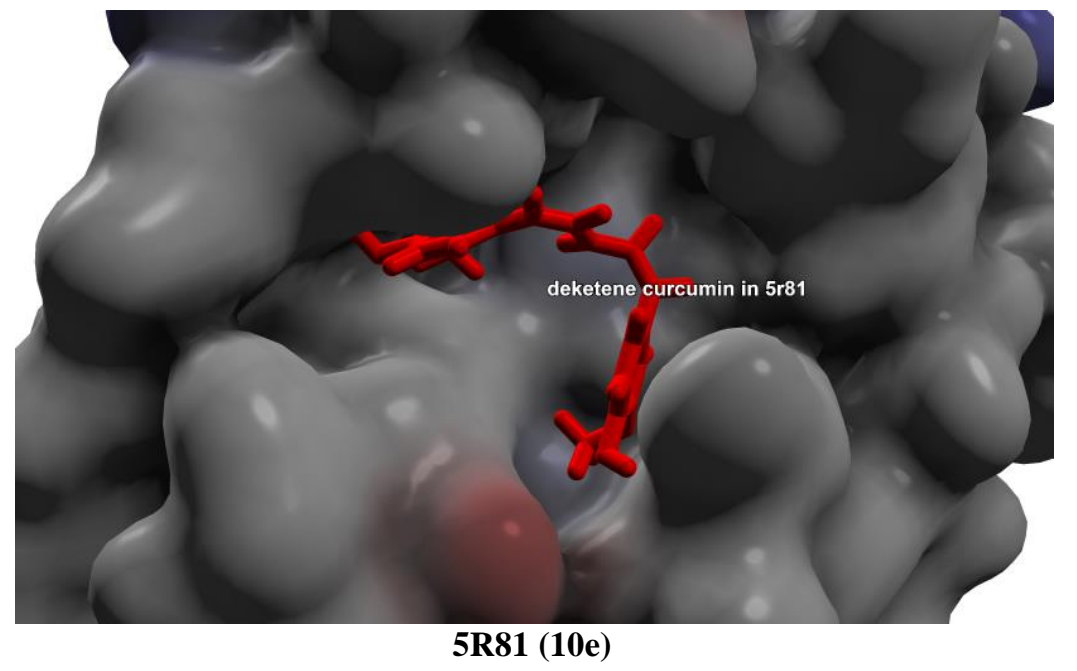

Figure 10(a-e): Binding of Deketene Curcumin with five Covid-19 Mpro 6LU7 (10a), 5R7Z (10b), 5R7Y (10c), 5R80 (10d) and 5 R81 (10e).

Ligand-protein interaction analysis of Deketene Curcumin with COVID-19 Mpro (PDB ID: 6LU7, 5R7Z, 5R7Y, 5R80, 5R81) which is illustrated in Table 2. The Physiochemical properties of Deketene Curcumin are illustrated in the table 3. 
Table 2: Hydrogen bond interaction between the Deketene Curcumin with five main Protease of COVID-19

\begin{tabular}{|c|c|c|c|c|c|c|}
\hline Ligand & PDB ID & $\begin{array}{l}\text { Interacting } \\
\text { amino acid }\end{array}$ & $\begin{array}{c}\text { Interacting } \\
\text { protein atom }\end{array}$ & $\begin{array}{c}\text { Interaction } \\
\text { energy }\end{array}$ & $\begin{array}{c}\text { Interaction } \\
\text { distance in } \AA\end{array}$ & $\begin{array}{l}\text { Interacting } \\
\text { ligand atom }\end{array}$ \\
\hline & 6LU7 & Cys 145 & SG & -2.5 & 3.09659 & O13 \\
\hline & & & $\mathrm{N}$ & -0.446054 & 3.0051 & $\mathrm{O} 15$ \\
\hline & & Leu 141 & $\mathrm{O}$ & -2.5 & 3.09932 & O15 \\
\hline & & Ser 144 & $\mathrm{O}$ & -0.771941 & 2.61461 & O15 \\
\hline & & & $\mathrm{N}$ & -0.751707 & 3.27658 & O15 \\
\hline & & Tyr 54 & $\mathrm{OH}$ & -2.13201 & 3.1736 & $\mathrm{O} 22$ \\
\hline & & & $\mathrm{OH}$ & -1.58468 & 3.28306 & $\mathrm{O} 24$ \\
\hline & & His 41 & ND1 & -0.494565 & 2.5235 & $\mathrm{O} 24$ \\
\hline & $5 \mathrm{R} 7 \mathrm{Z}$ & Glu 166 & OE2 & -0.549256 & 3.01141 & O15 \\
\hline & & Phe 140 & $\mathrm{O}$ & -2.5 & 2.84207 & O15 \\
\hline & & His 172 & NE2 & -2.04814 & 3.19037 & O15 \\
\hline & & Cyr 145 & SG & -2.5 & 3.09598 & O6 \\
\hline & & Arg 188 & $\mathrm{O}$ & -0.640154 & 3.1781 & $\mathrm{O} 24$ \\
\hline & & His 41 & ND1 & -0.680054 & 3.1044 & $\mathrm{O} 22$ \\
\hline \multirow[t]{15}{*}{$\begin{array}{l}\text { DEKETENE } \\
\text { CURCUMIN }\end{array}$} & $5 \mathrm{R} 7 \mathrm{Y}$ & Thr 25 & OG1 & -0.00618954 & 3.49494 & $\mathrm{O} 15$ \\
\hline & & & OG1 & -1.43818 & 3.02408 & $\mathrm{O} 13$ \\
\hline & & Ser 46 & $\mathrm{~N}$ & -0.964002 & 3.25903 & $\mathrm{O} 13$ \\
\hline & & Cyr 145 & $\mathrm{~N}$ & -1.87301 & 2.96697 & $\mathrm{O} 24$ \\
\hline & & Ser 144 & $\mathrm{~N}$ & -1.63445 & 2.65676 & $\mathrm{O} 24$ \\
\hline & & Leu 141 & $\mathrm{O}$ & -2.5 & 2.6008 & $\mathrm{O} 24$ \\
\hline & $5 \mathrm{R} 80$ & Asp 187 & $\mathrm{O}$ & -2.5 & 2.99879 & $\mathrm{O} 15$ \\
\hline & & Tyr 54 & $\mathrm{OH}$ & -1.22658 & 2.80247 & O15 \\
\hline & & His 41 & ND1 & -1.28059 & 2.63469 & $\mathrm{O} 13$ \\
\hline & & Gln 192 & NE2 & -0.334994 & 3.13987 & O6 \\
\hline & & Gln 189 & NE2 & -0.874633 & 3.39419 & $\mathrm{O} 24$ \\
\hline & $5 \mathrm{R} 81$ & Asn 142 & OD1 & -1.69465 & 3.11223 & O15 \\
\hline & & Cyr 145 & SG & -2.34332 & 3.13051 & $\mathrm{O} 13$ \\
\hline & & Ser 144 & OG & -1.04925 & 3.31765 & $\mathrm{O} 13$ \\
\hline & & Arg 188 & $\mathrm{O}$ & -2.5 & 2.85825 & $\mathrm{O} 24$ \\
\hline
\end{tabular}


Table 3: Physiochemical properties of Deketene Curcumin

\begin{tabular}{ccccccc}
\hline Ligand & $\begin{array}{c}\text { Hydrogen } \\
\text { Bond Donor }\end{array}$ & $\begin{array}{c}\text { Hydrogen } \\
\text { Bond } \\
\text { Acceptor }\end{array}$ & $\begin{array}{c}\text { Rotatable } \\
\text { Bond }\end{array}$ & $\begin{array}{c}\text { Molecular } \\
\text { Weight }\end{array}$ & $\begin{array}{c}\text { Topological } \\
\text { Polar Surface } \\
\text { Area }\end{array}$ & ClogP \\
\hline $\begin{array}{l}\text { DEKETENE } \\
\text { CURCUMIN }\end{array}$ & 2 & 5 & 6 & $326.3 \mathrm{~g} / \mathrm{mol}$ & $76 \AA^{2}$ & 2.6424 \\
\hline
\end{tabular}

\section{CONCLUSION}

To sum up the discussion it can be eventually stated that virtual screening based on molecular docking was performed to identify novel compound which can able to bind with protein structures of COVID-19 (PDB ID: 6LU7, 5R7Z, 5R7Y, 5R80, 5R81). Through molecular docking, the data which received it can be stated that deketene curcumin interacts with all pretended amino acids of COVID-19 protein structures and it has good binding potency against COVID-19 due to its medicinal properties. In the future, this compound could be used to gain interest of the many researchers for the initiation of the clinical trials.

\section{Conflicts of Interest}

The authors declare no conflict of interest.

\section{Acknowledgment}

We would like to express our special thanks of gratitude to both the organizations Itm Vocational University as well as M.S. University, Baroda, Gujarat, India. A part from this, appreciate the efforts of all the authors.

\section{REFERNCES}

1. P. Zhou, "A pneumonia outbreak associated with a new coronavirus of probable bat origin," Nature, vol. 579, no. 7798, pp. 270-273, 2020.

2. H. Yang, "Drug design targeting the main protease, the Achilles' heel of coronaviruses," Current pharmaceutical design, vol. 12, no. 35, pp. 4573-4590, 2006.

3. W.-j. Guan, "Clinical characteristics of coronavirus disease 2019 in China," New England journal of medicine, vol. 382, no. 18 , pp. $1708-1720,2020$.

4. Q. Lu, "Coronavirus disease (COVID-19) and neonate: What neonatologist need to know," Journal of medical virology, vol. 92 , no. 6 , pp. 564-567, 2020.

5. L. M. A. S. Y. P. Jie Y, "2019 novel coronavirus (2019-nCoV) and 2019-nCoV pneumonia.," Chin J Microbiol Immunol, vol. 40, no. 1, p. 1- 6, 2020.

6. Z. Gao, "Efficient management of novel coronavirus pneumonia by efficient prevention and control in scientific manner," Chinese journal of tuberculosis and respiratory diseases, vol. 43, pp. E001-E001, 2020.

7. Y. Chen, "Emerging coronaviruses: genome structure, replication, and pathogenesis," Journal of medical virology, vol. 92, no. 4, pp. 418-423, 2020.

8. K.-C. Chou, "Structural bioinformatics and its impact to biomedical science," Current medicinal chemistry, vol. 11, no. 16, pp. 2105-2134, 2004. 
9. K. Anbarasu, "Identification of curcumin derivatives as human LMTK3 inhibitors for breast cancer: a docking, dynamics, and MM/PBSA approach,” 3 Biotech, vol. 8, no. 5, p. 228, 2018.

10. I. N. Dahmke, "Cooking enhances curcumin anti-cancerogenic activity through pyrolytic formation of "deketene curcumin"," Food chemistry, vol. 151, pp. 514-519, 2014.

11. R. Thomsen, "MolDock: a new technique for high-accuracy molecular docking," Journal of medicinal chemistry, vol. 49, no. 11, pp. 3315-3321, 2006.

12. J. Sochacka, "Docking of thiopurine derivatives to human serum albumin and binding site analysis with Molegro Virtual Docker," Acta Pol. Pharm, vol. 71, pp. 343-349, 2014.

13. V. Mishra, "Ligand based virtual screening for identifying potent inhibitors against viral neuraminidase: An in silico approach," Journal of Taibah University for Science, vol. 9, no. 1, pp. 20-26, 2015.

Corresponding author*

Vraj R. Shah,

Email: vraj97966@gmail.com

Mobile No: +917016346471 